\title{
ABSORPTIVE CAPACITY OF INDUSTRIAL COMPANIES IN TRADITIONAL SECTORS IN THE STATE OF RIO GRANDE DO SUL, BRAZIL
}

\author{
CLAIR W. PUFFAL ${ }^{1}$ \\ (D) https://orcid.org/0000-0003-2853-236X \\ DANIEL P. PUFFAL ${ }^{2}$ \\ http://orcid.org/0000-0001-5962-4676 \\ YEDA S. SOUZA ${ }^{2}$ \\ (iD) https://orcid.org/0000-0001-9299-9509
}

To cite this paper: Puffal, C. W., Puffal, D. P., \& Souza, Y. S. (2019). Absorptive capacity of industrial companies in traditional sectors in the state of Rio Grande do Sul, Brazil. Revista de Administração Mackenzie, 20(6). doi:10.1590/1678-6971/eRAMD190066

Submission: Apr. 9, 2019. Acceptance: Aug. 23, 2019.

1 Serviço Brasileiro de Apoio às Micro e Pequenas Empresas (Sebrae), São Leopoldo, RS, Brazil.

2 Universidade do Vale do Rio dos Sinos (Unisinos), Porto Alegre, RS, Brazil.

\section{(cc) BY




\section{ABSTRACT}

Purpose: This study aimed to assess processes related to absorptive capacity (AC) dimensions in innovation-generating companies of traditional sectors in the State of Rio Grande do Sul, Brazil.

Originality/value: Companies may establish differential advantages in the market due to how far they apply acquired knowledge and use organizational mechanisms. These mechanisms include intangible elements essential to the development of AC, a capacity that companies do not often recognize as important to generate innovation. Based on previous studies, we established a summary of AC elements and AC within its different dimensions. Then we created an assessment tool for $\mathrm{AC}$ analysis and knowledge generation dynamics in innovative microprocesses in organizations of the traditional sectors.

Design/methodology/approach: Data were collected using a semi-structured questionnaire with 47 items to assess potential and realized AC and their dimensions. We assessed two companies on their AC. These companies were participants of a project of the Núcleo de Apoio à Gestão da Inovação (Nagirs) of Instituto Euvaldo Lodi (IEL) in the State of Rio Grande do Sul, Brazil, oriented to enhance innovation in traditional sectors. This study used content analysis and compared the evidence found with findings in the literature.

Findings: The results suggested that, in companies of traditional sectors, AC can be considered explicative to innovation generation and the organizational dynamics orchestrating mechanisms for knowledge renewal. Data reveals that knowledge renewal requires managers and qualified workers' engagement in search and application of external information that responds to the company's strategic challenges. The study also contributes to establishing an assessment tool for AC in companies of traditional sectors.

\section{KEYWORDS}

Absorptive capacity. Absorptive capacity dimensions. Innovation processes. Traditional sector. Innovation. 


\section{INTRODUCTION}

Although having an essential role in innovation management, knowledge dissemination, and organizational integration, absorptive capacity (AC) is still a dimension rarely considered in companies of traditional sectors. AC theory has its basis on the seminal study conducted by Cohen and Levinthal (1990), who described it as a company's capacity to recognize the value of information, assimilate it and apply it to commercial ends. It is a fundamental process for the development of any company's technological capacities. Zahra and George (2002) expanded on the premises developed by Cohen and Levinthal (1990) using a procedural approach based on a company's dynamic capacity, distinguishing potential AC ( $\mathrm{pAC}$ ) from realized AC (rAC) and contributing to the reconceptualization of AC.

The advancement of AC studies has defined a view of the processes and micro-processes of companies in the traditional sector. Researchers have focused attention on empirical studies that investigate possible indicators to measure organizational antecedents, which are important elements of a company's competitiveness and affect pAC and $\mathrm{rAC}$ in innovation processes. (Jansen, Van Den Bosch, \& Volberda, 2005; Volberda, Foss, \& Lyles, 2010; Tu, Vonderembse, Ragu-Nathan, \& Sharkey, 2006; Fosfuri \& Tribó, 2008; Vega-Jurado, Gutiérrez-Gracia, \& Fernández-de-Lucio, 2008; Camisón \& Forés, 2010; Flatten, Engelen, Zahra, \& Brettel, 2011; Jiménez-Barrionuevo, García-Morales, \& Molina, 2011; Xie, Zou, \& Qi, 2018). These studies have demonstrated that AC affects innovation through intra-organizational knowledge transfer and inter-organizational learning, thus facilitating the accumulation of knowledge and promoting its use (Soares \& Mazon, 2016).

The main objective of this study was to analyze processes and structures associated with AC dimensions in companies seen as innovative. Based on the main contributions of previous studies that assessed AC, we created a semi-structured questionnaire addressing AC dimensions, separated into categories for the qualitative organization of the data collected from two companies of the traditional sector in the State of Rio Grande do Sul (RS), Brazil. Their innovation processes were previously identified based on secondary data (Instituto Euvaldo Lodi do Rio Grande do Sul, 2016). After data collection, this study analyzed AC dimensions of the two companies, one in the food and beverage sector and the other one in the medical equipment sector. The study also contributes to establishing an assessment tool for AC in companies of traditional sectors. 


\section{ABSORPTIVE CAPACITY (AC)}

Cohen and Levinthal (1990) defined absorptive capacity (AC) as the capacity of an organization to assimilate and apply new information. They argued that it is a function of the diversity of prior knowledge of the members of the organization, who, according to the authors, is a factor that affects organizational AC and innovative performance. Another AC dimension, according to Cohen and Levinthal (1990), is the organization's ability to exploit external knowledge by using a certain level of prior knowledge, which should confer the ability to recognize the value of information and to assimilate and apply it to commercial ends.

AC depends on prior organizational knowledge, on knowledge of individual organizational members and is associated with investments in the search for external and internal information. These investments tend to generate cumulative organizational AC providing feedback on prior knowledge that is, in turn, further developed by new knowledge and the capacity to exploit it, thus creating an innovative environment. Different levels of this AC may be used, as it depends on how it is managed within the organization (Cohen \& Levinthal, 1990). As it hires individuals with prior knowledge, experience, and training adequate to the organization's profile, research, and development (R\&D) department contributes to the development of knowledge by its personnel. These actions generate an adequate structure to facilitate the company's capacity to organize, promote and transfer internal knowledge (Schillaci, Romano, \& Nicotra, 2013).

Martinkenaite and Breunig (2016) redefine AC as a set of sequentially linked exploratory and transformative learning processes, within which organizational antecedents and individuals interact. No theoretical arguments or conclusions have been reached about the development of innovation and performance, nor about the use of AC as a function of a company's age and time. However, Zou, Ertug, and George (2018), in a meta-analysis of AC studies about the capacity of companies to innovate, found that $\mathrm{AC}$ performance is indirect and mediated by both innovation and knowledge transfer. AC does not increase with a company's size or age, but the association of AC with company size is positive and significant for small companies and negative and significant for large ones. The analysis of age reveals that $\mathrm{AC}$ is not significant for new companies, but it is negative and significant for mature ones. Despite limited resources, small companies are more capable of innovation than large companies, which have more resources, but find it difficult to invest in training (Zou et al., 2018). 
Zahra and George (2002) based their study on the findings by Cohen and Levinthal (1990) to explain organizational phenomena by expanding the definitions of dimensions and reconceptualizing AC. They described AC as two subsets, potential $\mathrm{AC}$ (pAC), which includes knowledge acquisition and assimilation, and realized $\mathrm{AC}$ ( $\mathrm{rAC}$ ), a function of transformation and exploitation of knowledge.

The theoretical contributions made by Zahra and George (2002) were initially assigned to the understanding of $\mathrm{AC}$ as a set of organizational processes and routines that companies use to acquire, assimilate, transform and exploit knowledge. These processes establish a dynamic organizational capacity that affects the sustainability of any competitive advantage. According to other authors, this differentiation facilitates AC analysis, as researchers are able to investigate antecedents and consequences that may be changed by managerial actions. Their second contribution is the recognition of the importance of the different AC dimensions of a company and their effect on strategic choices. The specification and examination of these dimensions clearly demonstrate the development and progression of the dynamic capacities that determine the paths of organizational change. The third contribution made by those authors was the identification of the conditions for $\mathrm{AC}$ value creation using insights about relevant issues in the analysis of a company's evolution (Zahra \& George, 2002).

\subsection{Evaluation of AC}

Based on the recommendation made by Zahra and George (2002) to operationalize AC, researchers have investigated possible tools to measure $\mathrm{AC}$ and its dimensions and developed hypotheses, variables, and indicators. The measurement models for this construct have been validated in empirical studies.

Jansen et al. (2005) validated the conceptual difference between pAC and rAC suggested by Zahra and George (2002), focusing on organizational antecedents and examining the database of a large European financial firm. To measure AC, they classified organizational capabilities as combinative ones and divided them into three types: 1 . organizational mechanisms associated with coordination capabilities; 2 . organizational mechanisms associated with systems; and 3. organizational mechanisms associated with socialization capabilities. For each type, different expertise sources are incorporated and intensify the interaction between formal and informal structures, creating a favorable knowledge context. Volberda et al. (2010) classified AC types as managerial, intraorganizational, and interorganiza- 
tional, all directly linked to coordination, systems and socialization found in a company (Jansen et al., 2005).

The initial concept of organizational AC, defined by Cohen and Levinthal (1990), classifies external information as sources of knowledge that lead to continuous learning, having a cumulative effect. This definition was established in a study conducted by Tu et al. (2006), for whom it was implicit that companies acquire knowledge from internal sources. However, some companies may not have access or be aware of this. Therefore, those authors defined AC as "the organizational mechanisms that help to identify, communicate and assimilate relevant external and internal knowledge" (Tu et al., 2006, p. 3).

Fosfuri and Tribó (2008) have identified two different paths: the interaction with external sources of knowledge and the experience with knowledge search (Zahra \& George, 2002). The interaction with external sources of knowledge may occur through clients, competitors, consulting firms, universities and R\&D collaborations, which contribute to the experience of dealing with external information through different knowledge sources, as well as through outsourcing $R \& D$ contracts that provide the company with competencies necessary to participate in future partnerships or alliances (Aguilar-Olaves, Herrera, \& Clemenza, 2014; Fosfuri \& Tribó, 2008).

Vega-Jurado et al. (2008) investigated the difference between pAC and rAC established by Zahra and George (2002) and found that organizational antecedents may affect AC in different ways. They refer to knowledge attributes and focus on three groups of internal activities: 1. organizational knowledge, which comprehends the set of skills, knowledge and experience that the company has; 2 . formalization, which refers to the explicit procedures, rules and instructions in organizational processes that establish behavior models for employees; and 3. facilitation of communication between the company's departments and units and the mechanisms of social integration referring to the formal and informal practices that organize the company's knowledge systematically and reduce the barriers to exchanges. These are as important as the management of internal R\&D activities. However, in some cases, deviations from formal rules may be important to add flexibility to knowledge acquisition and to increase the level of AC in a company (Duchek, 2015). Camisón and Forés (2010) conducted further studies about the level of organizational analysis, which is not limited to technological knowledge and enables the examination of other types of knowledge. In pAC (acquisition), the authors evaluated knowledge of the competition, openness towards the environment and importance of R\&D cooperation with other institutions, companies, and universities. Organizations not 
prepared to manage institutional differences from academia seemed to lose effectiveness in assimilating available knowledge (Belderbos, Gilsing, \& Suzuki, 2016). Moreover, Camisón and Forés (2010) suggested that programs for the development of internal technological competences should be established based on the demands of suppliers or customers.

For pAC (assimilation), in turn, they evaluated a series of elements: the capacity of assimilation of new, useful technologies and innovations with a proven potential; employees' ability to assimilate, interpret and use new knowledge; use of successful experience of companies in the same industry (benchmarking); engagement of employees with scientific knowledge, such as presentation of scientific studies, teaching or reception of employees of other companies that develop research; participation in training courses and meetings; and, finally, the capacity to develop knowledge management and understand and analyze other companies' technologies. For rAC (transformation), the authors chose, among others, the following items: capacity to use information technology (IT) to facilitate information flow, share knowledge and promote communications between members of the company; capacity of renewal and adaptation; exchange of scientific information between employees; and capability to integrate all R\&D phases with engineering, production, and marketing. The indicators of rAC (exploitation) refer to the capacity to use and exploit new knowledge to respond to environmental changes, application of experience, capacity to develop patents and processes, and capacity to expand product and service portfolios due to competitive pressure (Camisón \& Forés, 2010).

For Lichtenthaler (2016), a technological and proactive market orientation has a positive effect on AC processes of exploration and retention, as well as the form that the company uses to apply its existing knowledge to create new knowledge and generate value, using research and innovation, a process called exploitation (March, 1991).

The study conducted by Flatten et al. (2011) used multidimensional measurements of AC and used proxies usually adopted in the literature, such as R\&D participation (Cohen \& Levinthal, 1990), number of patents (Ahuja \& Katila, 2001; Mowery, Oxley, \& Silverman, 1996) and intensity of R\&D participation (Belderbos, Carree, Diederen, Lokshin, \& Veugelers, 2004; Meeus, Oerlemans, \& Hage, 2001; Oltra \& Flor, 2003; Stock, Greis, $\&$ Fischer, 2001; Tsai, 2001). Therefore, Flatten et al. (2011) developed measurement parameters in which pAC (acquisition) shares intelligence generation and market-related knowledge. For pAC (assimilation), the authors set the focus on shared interpretations of acquired knowledge, as well as on dissemination of knowledge and learning of the whole company. 
According to the authors, rAC (transformation) is characterized by the development of existing resources to create new knowledge in combination with existing knowledge, overlapping previous knowledge, together with the generation of ideas, innovation capability, innovation management, and organizational learning. Studies in the literature paid little attention to rAC (exploitation), because their focus is on innovation capability and marketoriented response capability. Knowledge exploitation and creation have a common objective: the commercial use of knowledge through new products.

Jiménez-Barrionuevo et al. (2011) developed a scale to measure abilities to acquire, assimilate, transform, exploit and perceive AC. According to those authors, organizational mechanisms affect pAC and rAC in different ways. The capacity to coordinate improves potential capacities, whereas socialization reinforces the dimension of realized capacities. This explains why some units and companies are able to acquire new knowledge from the external environment, but are unable to apply it successfully.

The authors indicate that it is important to identify AC phases to avoid an imbalance between $\mathrm{pAC}$ and $\mathrm{rAC}$. If a company is capable of continuously renewing its knowledge stock by means of a concentration of efforts in the acquisition and assimilation of new external knowledge, it may be doing so in the capacity of pAC. Therefore, it may have high costs if it does not develop its abilities of transformation and exploitation of this knowledge. In this sense, Da Rosa \& Ruffoni (2014) suggested, in their study about AC measurement, that high assimilation in the company stands out as a relevant requisite to achieve high $\mathrm{AC}$.

In contrast, if these companies develop only the abilities of transformation and exploitation, they may obtain short-term benefits, falling into a trap and becoming incapable of responding to environmental changes. Therefore, if there is a balance, these companies may benefit from the knowledge and acquire a competitive advantage for a longer time and thus adapt to environmental changes (Jiménez-Barrionuevo et al., 2011).

\section{METHOD}

This is a case study (Yin, 2015) with the application of a qualitative data collection instrument in two companies in traditional industries in RS, Brazil. Cases were selected by using secondary data found in the final report of a project of the Núcleo de Apoio a Gestão de Inovação do Rio Grande do Sul (Nagirs), carried out from 2013 to 2015 and coordinated by Instituto Euvaldo Lodi do Rio Grande do Sul (IEL/RS). The objective of the Nagirs 
Project was to investigate the degree of innovation in industrial companies in RS that defined or started developing innovation structures and processes.

The main criteria to select the companies were: 1. participation in the Nagirs project between 2013 and 2016; 2. company was part of the traditional industrial sector in RS; and 3. company had established innovation processes and structures (Instituto Euvaldo Lodi do Rio Grande do Sul, 2016).

Seventy-two companies participated in the Nagirs project, and 12 of them met the selection criteria. After phone contacts, only two accepted to be part of the study.

The construction of this evaluation instrument consisted of the identification of elements that demonstrated AC development in previous studies, organized according to several authors, similar contexts of analysis, and AC organizational mechanisms. The elements found formed the basis for 12 categories used to identify the $\mathrm{pAC}$ and $\mathrm{rAC}$ dimensions of innovative processes in companies according to Zahra and George (2002).

Figure 3.1 shows the categories and references that were used as the basis for the analysis of the companies under study.

\section{(Figure 3.1)}

\section{CATEGORIES FOR AC ANALYSIS}

\begin{tabular}{|c|c|c|}
\hline Category & Authors & AC dimension \\
\hline $\begin{array}{l}\text { 1) Source of company knowledge } \\
\text { 2) Information search mechanisms } \\
\text { 3) Interaction between employees }\end{array}$ & $\begin{array}{l}\text { Fosfuri and Tribó (2008), Veja-Jurado et al. } \\
\text { (2008), Camisón and Forés (2010), Jiménez- } \\
\text {-Barrionuevo et al. (2011), Aguilar-Olaves } \\
\text { et al. (2014), Tu et al. (2006), Flatten et al. } \\
\text { (2011), Jansen et al. (2005), Volberda, Foss, } \\
\text { and Lyles (2010), and Xie et al. (2018) }\end{array}$ & pAC (acquisition) \\
\hline $\begin{array}{l}\text { 4) Basis of company knowledge } \\
\text { 5) Internal communications } \\
\text { 6) Training courses }\end{array}$ & $\begin{array}{l}\text { Tu et al. (2006), Jansen et al. (2005), } \\
\text { Volberda, Foss, and Lyles (2010), Jansen } \\
\text { et al. (2005), Volberda, Foss, and Lyles } \\
\text { (2010), Flatten et al. (2011), Camisón } \\
\text { and Forés (2010), and Xie et al. (2018) }\end{array}$ & pAC (assimilation) \\
\hline $\begin{array}{l}\text { 7) Effective employee participation } \\
\text { 8) Knowledge sharing - R\&D } \\
\text { departments } \\
\text { 9) Knowledge renewal capacity }\end{array}$ & $\begin{array}{l}\text { Jansen et al. (2005), Jiménez-Barrionuevo } \\
\text { et al. (2011), Tu et al. (2006), Camisón and } \\
\text { Forés (2010), Flatten et al. (2011), and } \\
\text { Xie et al. (2018) }\end{array}$ & rAC (transformation) \\
\hline $\begin{array}{l}\text { 10) Experience application } \\
\text { 11) Experience dissemination } \\
\text { 12) Capability to respond to } \\
\text { environment and competition }\end{array}$ & $\begin{array}{l}\text { Vega-Jurado et al. (2008), Camisón and } \\
\text { Forés (2010), Flatten et al. (2011), Tu et al. } \\
\text { (2006), Jiménez-Barrionuevo et al. (2011), } \\
\text { and Xie et al. (2018). }\end{array}$ & rAC (exploitation) \\
\hline
\end{tabular}

Source: Elaborated by the authors. 
Based on the literature, a questionnaire was prepared with 47 semistructured questions that investigated the elements of $\mathrm{AC}$ in its different dimensions, pAC (acquisition and assimilation) and rAC (transformation and exploitation). The questions received a code with a category number to indicate the $\mathrm{AC}$ dimension that the company used to develop its innovation processes, which facilitated AC analysis.

The questionnaire was validated by specialists in absorptive capacity, who applied it in face-to-face interviews recorded in the headquarters of the companies selected, called company A and company B. As the questionnaire was applied in person, respondents were able to describe processes in full and then explain each one in detail. Only excerpts where there was evidence of AC were selected for analysis.

Figure 3.2 shows the characteristics of respondents in companies A and B, whose interviews were conducted in November, 2015, and lasted an average of 60 minutes.

\section{(Figura 3.2)}

CHARACTERISTICS OF RESPONDENTS

\begin{tabular}{clcl}
\hline Code & \multicolumn{1}{c}{ Position } & Time in company & \multicolumn{1}{c}{ Degree in } \\
\hline EA1 & Managing director & 13 years & Business administration \\
\hline EA2 & HR manager & 10 years & HR management \\
\hline EA3 & Quality system supervisor & 13 years & Business processes \\
\hline EB1 & Production manager $~$ & 3 years & Product design \\
\hline EB2 & Industrial manager II & 16 years & Automation technology \\
\hline EB3 & Director & 25 years & Business administration \\
\hline EB4 & Commercial manager & 3 years & Business administration \\
\hline EB5 & Administrative manager & 6 years & Law \\
\hline
\end{tabular}

Source: Elaborated by the authors.

As only two companies were included, the volume of responses did not justify the use of software for analysis. Therefore, the study used content analysis and descriptive comparisons between the evidence found and findings in the literature.

\section{CASE DESCRIPTION}

We present below a brief description of the history of each company (A and $\mathrm{B}$ ) and the $\mathrm{AC}$ elements identified in the innovation processes. This 
description is based on the responses to the questionnaire applied to companies A and B. They were separated by categories that are part of a set of organizational processes and routines to acquire, assimilate, transform and exploit knowledge and thus create a dynamic organizational capacity to develop innovation (Zahra \& George, 2002).

\subsection{Company A}

Company A, a family business in the traditional food and beverage sector, was founded in 1924. It began operating by producing 200 bottles of soft drinks per day. For many years, it remained a small company serving only the local community. The second generation started managing the company in the 1960s, adopting an entrepreneurial leadership on a growth track.

Several strategic changes have taken place since the 1970s. It started investing in technology, laboratories, and equipment to improve its productive capacity. In 2002, the third generation leadership, facing challenges to change its management model and establish a quality system, contributed to the development of processes and the creation of a structure supported by quality and innovation. Its CEO's knowledge and experience led to the modernization of its soft drink production, and today it has a competitive advantage on the quality of its products and its competent product distribution. The company keeps its staff motivated to search for new knowledge and adapt it to its processes, according to the companies' needs.

Below, we describe the elements of each AC dimension identified in company A in the defined.

\section{1) $\mathrm{PAC}$ acquisition}

- Category 1 - source of knowledge: the development of organizational knowledge relates to the company's experiences along time; there is formal and informal exchange of information and internal knowledge between departments; suppliers are a source of knowledge on new products development.

- Category 2 - mechanisms to search for external information: commercial area and suppliers provide external information constantly; participation in benchmarking visits and training courses; meetings, fairs, workshops.

- Category 3 - interaction between employees during information search: managers and directors motivate employees to search for information; there are manuals with guidelines for employees to search for information from 
relevant sources during benchmarking visits and training courses; there are meetings of employees and their leaders to discuss departmental issues, later taken to the board of directors by managers; indirect participation in strategic management decision-making; employees make suggestions and disseminate ideas using specific channels, with subsequent responses, all duly recorded.

2) PAC assimilation

- Category 4 - knowledge-based and employee's problem-solving capabilities: managers have the required skills to manage daily operations; managers and employees on the front line have at least a higher education degree; operators and supervisors have autonomy and competence to solve technical problems; training and development courses are offered to employees to address technical shortcomings; the company has eight interdepartmental technical committees to address specific issues and find solutions for problems.

- Category 5 - internal communication: use of several means of communications such as phone contacts, electronic mail, social networks, and bulletin boards, which generates noise and does not lead to an ideal and efficient method of communication; the most efficient forms of communication between departments are formal and informal meetings, such as hallway meetings.

- Category 6 - training courses: annual budgets consider resources for managerial and technical training courses, visits to companies and national and participation in international fairs either for employees, managers, and directors according to needs at every department; directors and managers provide monthly internal lectures to employees, visitors, and students.

3) rAC transformation

- Category 7 - effective employee participation: managers and supervisors participate in interdepartmental meetings; strategic interdepartmental committees support the implementation of specific product or process projects; there are leadership development programs, which include job rotations between departments.

- Category 8 - sharing knowledge and coordination with R\&D and other departments: use of external R\&D (suppliers); development of new products by sharing relevant departmental information in meetings with the company's laboratory and supplier's R\&D, with the participation of multidisciplinary groups in the beginning and in the conclusion of the 
project; sharing of acquired knowledge in meetings and using information technologies, such as software, from the operational to the strategic level; employees' ideas and suggestions are discussed in weekly meetings with the department supervisor and in a specific program, which includes all company members; workshops to share information brought from fairs and seminars, as well as other relevant information from different departments published in the internal newsletter and physical or virtual bulletin boards.

- Category 9 - knowledge renewal capacity: employees associate their knowledge with those acquired externally and register it in a specific program after evaluation, using established criteria; management motivates employees to add changes that may be done on their scope of operations.

\section{4) rAC exploitation}

- Category 10 - application of acquired experience (prototypes, patents, trademarks): application of acquired external knowledge with investment in industrial production technology (machines and equipment) and in mobile communications technology to help the company manage the commercial department more flexibly; development of new products to innovate processes or management; tests of the use of management tools with the support of external consultants and internal strategy committees; national and international trademarks.

- Category 11 - communication of acquired experience: employee commitment to bringing in and sharing information in the company; responsiveness of employees and managers to new experiences and ideas.

- Category 12 - capacity to respond to environment and competition: accumulated organizational knowledge supports the implementation of projects developed to supply market demands and to respond to the company's strategies. Creation of scenarios and different responses to different environments, organized by risk management; experience of directors and managers and the teams' expertise, associated with new knowledge, motivates employees to innovate and develop new products; some restrictions to growth, such as limited physical space and production capacity to respond to market demands and expand its product portfolio; the company's competitive advantage is its product distribution.

\subsection{Company B}

Company B was founded in Caxias do Sul, a city in the mountainous area of RS. In 1978, it was bought and moved into its own building and, for 
many years, it was known as the largest TV repair company in RS. Between 1980 and 1990, it also excelled in medical equipment repair. During that time, the company's founder kept contact with foreign companies and engaged in continuous training, thus acquiring technical knowledge, also through visits to large electronic appliance manufacturers. As a result, he became familiar with quality production methods and next-generation technologies in this sector.

Starting in 1999, the company stood out in the Brazilian market of electro-medical equipment for aesthetic procedures, which demanded greater levels of qualification, productivity, research, and development in the company. In 2000, it realigned its production processes and outsourced the manufacture of components, while keeping $100 \%$ of the assembly line.

In 2004, one of the founder's children reorganized the company's structure and took its products to the international market. Between 2007 and 2008, company B became a technological leader in the Brazilian market of aesthetics products, a position achieved by its pioneering launching of radiofrequency devices in this market. That brought significant strategic changes to the company, such as the introduction of $R \& D$ and the reformulation of its management model to meet its expansion into the international market and the introduction of devices in the medical market.

The elements of each AC dimension identified in company B in the categories defined in this study are described below.

\section{1) $\mathrm{pAC}$ acquisition}

- Category 1 - source of knowledge: organizational knowledge acquired from experience and knowledge accumulated by the company and its founder, importance assigned to the experience of employees that worked in other companies; internal knowledge exchange in formal and informal meetings, such as hallway meetings; partnerships with 18 dealers and input suppliers and ten national and international universities; although R\&D department was organized, the company sometimes developed devices in association with a supplier's R\&D or a teaching institution.

- Category 2 - mechanisms to search for external information: most relevant external information is obtained by the directors and the commercial department; participation in fairs and contacts with customers and dealers; managers and employees acquire information through benchmarking visits, customers, journal subscriptions, internet articles; other publications in the area, consultants, specialists, and field work and research conducted in association with universities and professional 
associations; informal internal development of technological acquisitions; company learns with suppliers and customers by means of research, product trials, tests and prototype creation, a process divided into project, preparation and implementation, until the product reaches the market.

- Category 3 -interaction between employees during information search: employees are motivated to search for information by means of participation in fairs; employees are encouraged to engage in new challenging opportunities in the company, such as job rotation between departments, to make them feel motivated to acquire new information and apply their knowledge; strategic decisions are made by directors and managers; all employees, represented by their managers, have an indirect participation in strategic decisions; formal definition of processes, work guidelines and roadmap for activities.

\section{2) PAC assimilation}

- Category 4 - knowledge base and employee's problem-solving capabilities: most employees have at least an undergraduate degree, and managers, a graduate degree; technical knowledge held by engineers, physical therapists and aestheticians is seen as above average by other workers in the area; teams work in specific areas, but, when there are difficulties in meeting goals, managers organize a task force to obtain expected results.

- Category 5 - internal communications: meetings between managers in different departments; communications by means of phone, electronic mail, social networks, and apps; rapid flow of information to all the company, as lack of time leads to lost opportunities; information flow works better between managers, as their group is smaller.

- Category 6 - training courses: managers and supervisors participate in fairs in the sector; in-company training is given to employees that need to improve their skills and update their knowledge of changes in regulations, refresher courses, software updates and platform changes; industrial benchmarking; in-company lectures for customers, dealers, and university professors.

\section{3) rAC transformation}

- Category 7 - effective employee participation: employee participation in product development and strategic decision making informal monthly inter-departmental meetings; job and department rotation to motivate 
learning of internal processes of different departments; financial incentives for the production of academic papers relevant to the department in which the employee works.

- Category 8 - sharing knowledge and coordination with R\&D and other departments: suggestions and ideas are shared informally between managers and directors; ideas are freely discussed, exhibited on a suggestions board and approved in each department; for communications, R\&D and other departments use a project management method, which begins with the classification of a suggestion, its technological domain and its technical, commercial and financial feasibility. After that, there are theoretical and practical development of the device, tests, commercial contacts, marketing and, finally, its pilot production; periodic publication of informative bulletins prepared by the engineering department, as well as technical bulletins that accompany the product.

- Category 9 - knowledge renewal capacity: employees are able to use their knowledge and apply it to their practical activities; continuous renewal; some processes are followed up and carefully analyzed from trial period to contract execution.

\section{4) rAC exploitation}

- Category 10 - application of acquired experience (prototypes, patents, trademarks): partner reliability contracts, commercial contracts with dealers and suppliers; contracts and agreements with universities and contract addenda for projects carried on, with confidentiality clauses; credibility and reliability in the use of equipment by customers is one of the results of knowledge applied by the company staff; company has no patents or trademarks because of the discrepancies between competent authorities and the dynamics of the Brazilian market; improvement of devices confirms the company's capacity to apply acquired knowledge; support of internal and external researchers; support of managers and directors for the manufacture of prototypes.

- Category 11 - communication of acquired experience: ideas and suggestions shared are first recorded at the time of pre-project preparation; suggestions undergo technical, financial and commercial evaluations; all the departments are responsible for contributing information and thinking about innovations for the department and for the whole company.

- Category 12 - capacity to respond to environment and competition: the company has a strategic market approach when responding to environmental changes, searching for solutions through scientific studies and complying 
with the sector's norms. Its competitive advantage over the competition lies on the fact that it provides services and manufactures its own equipment.

\section{DATA ANALYSIS AND DISCUSSION}

The detailed description in this study provided the opportunity to analyze both companies using a perspective of AC and innovation, and to examine the evidence of $\mathrm{AC}$ at the different ages and maturity levels of the companies. Company $\mathrm{A}$ is a large and mature company in the food and beverage sector, existing for over 90 years. Company B, in contrast, is a small business, but also mature at 50 years of age, and produces electromedical equipment.

\section{1 pAC (acquisition)}

The analysis of companies A and B revealed the existence of an innovation process focused on market demands, the internal integration of employees, and the external collaboration with input suppliers. They reported on a similar growth evolution in diverse environments and market changes, as well as the accumulation of knowledge and experiences, which are antecedents of organizational AC (Zahra \& George, 2002; Jansen et al., 2005; Fosfuri \& Tribó, 2008).

Company A does not have an internal R\&D department, but establishes partnerships with its main suppliers to develop new products, using their R\&D (Fosfuri \& Tribó, 2008; Camisón \& Forés, 2010). However, one can notice a lack of confidentiality contracts with suppliers placed by a trustbased relation on product development. Trust-based relations may result in some imbalance between the pAC and rAC dimensions (Jiménez-Barrionuevo et al., 2011) because the competitive advantage will be held for a short term only.

In contrast, company $\mathrm{B}$ has a structured internal $\mathrm{R} \& \mathrm{D}$ department, a determinant of AC, according to Cohen and Levinthal (1990) and Vega-Jurado et al. (2008). Partnerships with dealers enable external sources of information, some input suppliers and national and international universities, which is in agreement with the concept of openness toward the environment to which Camisón and Forés (2010) refer. To develop products or conduct tests, the company may use the R\&D department of its suppliers or of a 
teaching institution. It should keep confidentiality contracts with these partners for the exchange of technology, as well as supply contracts and formal agreements with universities.

\section{2 pAC (assimilation)}

The front line employees in companies A and B have at least an undergraduate degree, but there is a higher number of employees with a graduate degree in company B. Hiring people with higher levels of schooling to develop products based on scientific studies and in partnerships with universities accelerates the mechanisms of pAC development. The technical knowledge of employees in the two companies is substantially high, which facilitates the assimilation of the information acquired externally.

Companies A and B form teams to work in specific areas. Company A has interdepartmental technical committees (Jansen et al., 2005) to assimilate specific topics and to solve problems. They may be classified as the internal gatekeepers mentioned by Cohen and Levinthal (1990) and Jones (2006), as they provide support for socialization and for the choice of company strategies. Company B has no committees, but if there is any difficulty in a specific area, the departments cooperate to achieve goals or obtain results.

Communication in both companies occurs in multidisciplinary meetings (Jansen et al., 2005; Flatten et al., 2010), through phone and electronic mail, on social networks and using apps and mechanisms that enhance connectedness, socialization. Their interface between functions was classified as a positive factor to increase pAC by Jansen et al. (2005). There is a rapid flow of information in both companies and, although important and necessary, there are lost opportunities, because of the little time for assimilation of the information received. The variety of communications means, on one hand, that communication is positive, but if communications are not efficiently directed, the process may generate noise and adversely affect AC intensity.

There were similarities between the companies, also in how they improve employees' skills and contribute to their capacity to assimilate new technologies. Companies A and B provide specific in-company training courses, software refresher courses, industrial benchmarking visits, participation in national and international fairs and management training courses, as well as technical visits to improve managers' and employees' skills to assimilate new information and incorporate new forms of action, adapted to the company's reality (Camisón \& Forés, 2010). 


\section{3 rAC (transformation)}

Companies $\mathrm{A}$ and $\mathrm{B}$ engage managers and supervisors to participate in the company's decision-making process through interdepartmental meetings and organization of strategic committees to support specific actionable processes, or to discuss the development of trends and innovations. The development of a new product in company A has the participation of a multidisciplinary committee, which includes the marketing, commercial and financial departments and provides support for the first and last phases of the project. The company laboratory, in turn, follows up each step of the development together with the supplier's R\&D department (Jansen et al., 2005; Jiménez-Barrionuevo et al., 2011).

Company $\mathrm{B}$ can coordinate the steps of the R\&D process with other departments (Camisón \& Forés, 2010). This company has a structured R\&D department, and, therefore, its interaction mechanisms are inherent to the systematic process, which facilitates the methodical follow-up of each project and contributes to the development of rAC. The company provides incentives for employee job rotation between departments, which improves their motivation and effective collaboration employing efforts to learn and contribute to the acquisition of personal and company knowledge. Moreover, there is an opportunity for the department to increase the capacity of association of new and already existing knowledge in the company (Cohen \& Levinthal, 1990).

In both companies, innovation generation was incremental, which confirms their capacity to coordinate the flow of information and to transmit acquired knowledge using the software at different levels, from operational to strategic, which improves communications between departments. Therefore, and in agreement with Camisón and Forés (2010) and Jiménez-Barrionuevo et al. (2011), the companies use IT as an ally in the development of their rAC. Moreover, they keep records, reports, and documents for the management of processes, as well as for the dissemination of relevant information using in-company newsletters, informative bulletins, lectures and workshops, which are important means of communications according to Jiménez-Barrionuevo et al. (2011) and Flatten et al. (2010).

\section{4 rAC (exploitation)}

Company A develops innovation together with its supplier's $R \& D$ department and its in-company laboratory, where tasting tests are conducted, 
involving an internal multidisciplinary team. For the purchase of new production or management supplies, use and applicability tests are conducted under the guidance of an external consulting firm and an internal team of managers. The company's differential advantage is distribution as a service innovation, which should be classified as an appropriability regime that supports a performance difference, according to Zahra and George (2002). Therefore, the results found in this study, which made rAC evident, do not refer only to incremental innovations, but also to knowledge renewal and accumulation to improve strategic decision-making in the company.

In company B, in contrast, the application of knowledge leads to credibility and reliability in the use of equipment by end-users and universities that share suggestions, follow up development, and provide feedback. Because of that, the company has achieved its strategic objective, which was to introduce its equipment in the medical area and increase sales by operating in the international market. For that purpose, acquired organizational knowledge was added to the company's previous knowledge base and, thus, led to rAC (Vega-Jurado et al., 2008).

The innovations developed by companies $\mathrm{A}$ and $\mathrm{B}$ have not been patented in the competent governmental offices. Company A chose to register only its products' trademarks in national and international organs. Company B only registered the names of the aesthetic procedures that it has developed in the competent registration offices. A patented product may work as a mechanism of protection to ensure commercial results (Cohen \& Levinthal, 1990; Camisón \& Forés, 2010), which some authors consider to be a competitive advantage resulting from a regime of appropriability (Zahra \& George, 2001). Brazilian bureaucracy, however, which is part of patenting in this country, gives competitors room to make copies, as it may expose a company's knowledge that takes two years to be acquired and assimilated, the estimated time to develop a new device or service in the companies studied.

\section{CONCLUSION}

This study aimed to assess processes related to AC dimensions in innovation-generating companies of traditional sectors in the State of Rio Grande do Sul (RS), Brazil. Data collection and analysis provided a detailed view of the practices carried out to develop AC dimensions in companies of two traditional sectors in RS. The result of this analysis suggests that there is evidence of the development of AC in the two companies included in the study. According to other authors, industrial companies that innovate, 
regardless of their size or sector, keep an organizational dynamic that includes mechanisms to search for renewal of existing knowledge by engaging skilled managers and employees in acquiring and assimilating external information, according to the strategic challenges posed by the company.

This study found that pAC has some particular characteristics, such as different sources of information, more or less intense strategic partnerships, internal $\mathrm{R} \& \mathrm{D}$ organizations to establish the structure of its projects, and different perceptions of the importance of reliability contracts between partners. At the same time, there are similarities in acquisition and assimilation mechanisms, such as the use of training courses, benchmarking visits, visits to fairs, routine formal meetings, multidisciplinary teams, and interaction between employees. The purpose of these procedures is to transform their knowledge into results for the company using a documented process.

For rAC, in both companies, in contrast, despite the different environments and histories, similar solutions were developed. They included the generation of incremental innovation based on the ability to face market changes, as well as on the continuous improvement of the company and the definition of strategic choices contributing to the development of competencies that are different from those of their competitors'.

The analysis of $\mathrm{AC}$ dimensions in companies $\mathrm{A}$ and $\mathrm{B}$ revealed that they have similar levels of maturity. Both had an important AC antecedent, the previous knowledge of their founders, and, as time went by, the accumulation of knowledge through mechanisms developed by the companies. Therefore, they adapted to changes in their environment, which suggests the existence of a significant association between $\mathrm{AD}$ and the companies' innovation processes.

Companies A and B were different in size. Company A is large, and, although it uses its knowledge and applies it to product and service innovation, it relies heavily on external and suppliers' knowledge for its development, which suggests the existence of a less intense or significant association with AC for innovation. Company B, which is small, is constantly searching for product development within the company through its R\&D department. Therefore, it contributes to the qualification of employees and the establishment of differences from the rest of its industrial sector, which defines a more positive and significant association with AC.

These analyses revealed that, although the companies included in the study use mechanisms to develop AC, they do not recognize its dimensions and components. Because of that, this study investigated evidence of an intangible capacity in the companies in the traditional sector and found that 
AC plays an important role, maybe even essential for the development of several types of capacities in a company.

This study suggests that companies in the traditional sector that have innovative characteristics may be evaluated to demonstrate innovation micro-processes in light of AC and to identify simple elements in the company's "black box" to improve management efficacy. Dimensions are interdependent; pAC supports effectivity in incorporating knowledge, which ensures that the company is prepared to face challenges. At the same time, rAC demonstrates the results of the skills developed through acquired knowledge, which generates innovations of any nature, or the company's capacity to choose better strategic paths, which is part of its evolution.

The contribution of this study is the development and application of an instrument to analyze $\mathrm{AC}$ in processes and structures whose purpose is innovation. It identifies the $\mathrm{AC}$ dimensions found from initial processes to effective innovation. For companies, there are advantages in knowing the dimensions of their AC, such as the ability to identify flaws in the process, improve management, and develop organizational capacity.

The preparation of a data collection instrument and its application contributes to the consolidation of studies about AC. One of the empirical contributions of this study is the finding that company maturity may be an important antecedent for AC development, whereas company size may not affect AC development. The existence of an R\&D department also seems to be relevant.

The results reported here cannot be used to define a linear behavior for traditional companies that have innovation processes, as only two Brazilian industrial companies were included, and results cannot be generalized.

\section{$\int$ ACKNOWLEDGEMENTS}

We thank the financial support from Capes through the Projects Capes/SIU 88881.153845/2017-01 and Capes/Proex 23038.009354/2018-25. 


\section{UMA ANÁLISE DA CAPACIDADE ABSORTIVA EM EMPRESAS DE SETORES TRADICIONAIS DO RIO GRANDE DO SUL}

\section{RESUMO}

Objetivo: Avaliar processos relacionados às dimensões da capacidade absortiva (CA) em empresas de setores tradicionais do Rio Grande do Sul que desenvolvem inovações.

Originalidade/valor: As empresas podem se diferenciar no mercado pelo nível de aplicação de conhecimento adquirido e utilização de mecanismos organizacionais, que apresentam elementos considerados intangíveis para o desenvolvimento da CA, ainda pouco reconhecida entre as empresas como capacidade importante para o desenvolvimento de inovações. A partir de estudos anteriores, reuniram-se elementos da CA em suas dimensões e elaborou-se um instrumento de avaliação da CA a fim de analisar a dinâmica de geração de conhecimento em microprocessos de inovação, sob um olhar da CA no contexto organizacional em setores tradicionais.

Design/metodologia/abordagem: Os dados foram coletados por meio de um questionário semiestruturado com 47 perguntas que abrangem elementos da CA potencial e CA realizada em suas dimensões, aplicado em duas empresas que apresentam processos de inovação comprovados no relatório do Projeto Nagirs, do banco de dados do Instituto Euvaldo Lodi do Rio Grande do Sul (IEL/RS). Optou-se por uma análise de conteúdo e por sua comparação descritiva das evidências em relação à literatura.

Resultados: Os resultados sugerem que, em empresas de setores tradicionais, a CA pode ser explicativa para o desenvolvimento de inovações e para a sustentação de uma dinâmica organizacional com mecanismos de busca de renovação do conhecimento, envolvendo gestores e funcionários habilitados na busca e assimilação de informações externas a partir de desafios estratégicos da empresa. O estudo contribui também para o desenvolvimento do instrumento de avaliação de CA em empresas de setores tradicionais. 


\section{PALAVRAS-CHAVE}

Capacidade absortiva. Dimensões da capacidade absortiva. Processos de inovação. Empresas tradicionais. Inovação.

\section{REFERENCES}

Aguilar-Olaves, G., Herrera, L., \& Clemenza, C. (2014). Capacidad de absorción: Aproximaciones teóricas y empíricas para el sector servicios. Revista Venezolana de Gerencia, 19(67), 499-518.

Ahuja, G., \& Katila, R. (2001). Technological acquisitions and the innovation performance of acquiring firms: A longitudinal study. Strategic Management Journal, 22(3), 197-220.

Belderbos, R., Carree, M., Diederen, B., Lokshin, B., \& Veugelers, R. (2004). Heterogeneity in $\mathrm{R} \& \mathrm{D}$ cooperation strategies. International Journal of Industrial Organization, 22 (8-9), 1237-1263.

Belderbos, R., Gilsing, V. A., \& Suzuki, S. (2016). Direct and mediated ties to universities: "Scientific" absorptive capacity and innovation performance of pharmaceutical firms. Strategic Organization, 14(1), 32-52,

Camisón, C., \& Forés, B. (2010). Knowledge absorptive capacity: New insights for its conceptualization and measurement. Journal of Business Research, 63(7), 707-715.

Cohen, W. M., \& Levinthal, D. A. (1990). Absorptive capacity: A new perspective on learning and innovation. Administrative Science Quarterly, 35(1), 128-152.

Da Rosa, A. C., \& Ruffoni, J. (2014). Mensuração da capacidade absortiva de empresas que possuem interação com universidades. Economia e Desenvolvimento, 26(1), 80-104.

Duchek, S. (2015). Designing absorptive capacity? An analysis of knowledge absorption practices in German high-tech firms. International Journal of Innovation Management, 19(4), 1550044.

Flatten, T. C., Engelen, A., Zahra, S. A., \& Brettel, M. (2011). A measure of absorptive capacity: Scale development and validation. European Management Journal, 29(2), 98-116. 
Fosfuri, A., \& Tribó, J. A. (2008). Exploring the antecedents of potential absorptive capacity and its impact on innovation performance. Omega, 36(2), 173-187.

Instituto Euvaldo Lodi do Rio Grande do Sul (2016). Manual de gestão da inovação. Porto Alegre: IEL/RS.

Jansen, J. J., Van Den Bosch, F. A., \& Volberda, H. W. (2005). Managing potential and realized absorptive capacity: How do organizational antecedents matter? Academy of Management Journal, 48(6), 999-1015.

Jiménez-Barrionuevo, M. M., García-Morales, V. J., \& Molina, L. M. (2011). Validation of an instrument to measure absorptive capacity. Technovation, $31(5-6), 190-202$.

Jones, O. (2006). Developing absorptive capacity in mature organizations: The change agent's role. Management Learning, 37(3), 355-376.

Lichtenthaler, U. (2016). Determinants of absorptive capacity: The value of technology and market orientation for external knowledge acquisition. Journal of Business \& Industrial Marketing, 31 (5), 600-610.

March, J. G. (1991). Exploration and exploitation in organizational learning. Organization Science, 2(1), 71-87.

Martinkenaite, I., \& Breunig, K. J. (2016). The emergence of absorptive capacity through micro-macro level interactions. Journal of Business Research, 69(2), 700-708.

Meeus, M. T., Oerlemans, L. A., \& Hage, J. (2001). Patterns of interactive learning in a high-tech region. Organization Studies, 22(1), 145-172.

Mowery, D. C., Oxley, J. E., \& Silverman, B. S. (1996). Strategic alliances and interfirm knowledge transfer. Strategic Management Journal, 17(S2), 77-91.

Oltra, M. J., \& Flor, M. (2003). The impact of technological opportunities and innovative capabilities on firms' output innovation. Creativity and Innovation Management, 12 (3), 137-144.

Schillaci, C. E., Romano, M., \& Nicotra, M. (2013). Territory's absorptive capacity. Entrepreneurship Research Journal, 3(1), 109-126.

Soares, T. C., \& Mazon, G. (2016). Autoavaliação e seus drives de mudança institucional baseado na capacidade absortiva. Revista Ibero-Americana de Estratégia, 15(4), 77-90.

Stock, G. N., Greis, N. P., \& Fischer, W. A. (2001). Absorptive capacity and new product development. The Journal of High Technology Management Research, 12(1), 77-91. 
Tsai, W. (2001). Knowledge transfer in intra-organizational networks: Effects of network position and absorptive capacity on business innovation and performance. Academy of Management Journal, 44(5), 996-1004.

Tu, Q., Vonderembse, M. A., Ragu-Nathan, T. S., \& Sharkey, T. W. (2006). Absorptive capacity: Enhancing the assimilation of time-based manufacturing practices. Journal of Operations Management, 24(5), 692-710.

Vega-Jurado, J., Gutiérrez-Gracia, A., \& Fernández-de-Lucio, I. (2008). Analyzing the determinants of firm's absorptive capacity: Beyond R\&D. RED Management, 38(4), 392-405.

Volberda, H. W., Foss, N. J., \& Lyles, M. A. (2010). Absorbing the concept of absorptive capacity: How to realize its potential in the organization field. Organization Science, 21(4), 931-951.

Xie, X., Zou, H., \& Qi, G. (2018). Knowledge absorptive capacity and innovation performance in high-tech companies: A multi-mediating analysis. Journal of Business Research, 88, 289-297.

Yin, R. K. (2015). Estudo de caso: Planejamento e métodos. Porto Alegre: Bookman.

Zahra, S. A., \& George, G. (2002). Absorptive capacity: A review, reconceptualization, and extension. Academy of Management Review, 27(2), 185-203.

Zou, T., Ertug, G., \& George, G. (2018). The capacity to innovate: A metaanalysis of absorptive capacity. Innovation, 20(2), 87-121.

EDITORIAL BOARD

Editors-in-chief

Janette Brunstein

Silvia Marcia Russi de Domênico

Associated Editor

Carlos Ricardo Rossetto

Technical Support

Vitória Batista Santos Silva

\section{EDITORIAL PRODUCTION}

Publishing Coordination

Jéssica Dametta

Language Editor

Daniel de Almeida Leão
Layout Designer
Emap

Graphic Designer

Libro 